\title{
Retinoic acid suppresses IL-17 production and pathogenic activity of $\gamma \delta$ T cells in CNS autoimmunity
}

\begin{abstract}
Mathilde Raverdeau ${ }^{1}$, Conor J Breen ${ }^{2}$, Alicja Misiak ${ }^{1}$ and Kingston HG Mills ${ }^{1}$
Retinoic acid (RA) in the steady state enhances induction of Foxp $3^{+}$regulatory T (Treg) cells and inhibits differentiation of Th1 and Th17 cells, thereby maintaining tolerance, but can in inflammatory conditions promote effector Th1 and Th17 cells that mediate inflammation. IL-17-producing $\gamma \delta \mathrm{T}$ cells have recently been shown to have a major pathogenic role in autoimmune diseases. Here, we examined the immunomodulatory effects of RA on $\gamma \delta$ T cells. We found that RA had a dramatic suppressive effect on IL-17A and IL-17F production by $\gamma \delta$ T cells stimulated with IL-1 $\beta$ and IL-23. RA suppressed ROR $\gamma$ t, IL-1R and IL-23R expression in $\gamma \delta \mathrm{T}$ cells. Treatment of mice with RA suppressed IL-17 production by $\gamma \delta \mathrm{T}$ cells in vivo. Furthermore, treatment of T cells with RA attenuated their ability to induce disease in experimental autoimmune encephalomyelitis (EAE), a murine model for multiple sclerosis. This was associated with a reduction in the number of central nervous system-infiltrating $\gamma \delta \mathrm{T}$ cells, but also CD4+ $\mathrm{T}$ cells that produced IL-17A, IL-17F or GM-CSF. Interestingly, treatment of $\gamma \delta$ T cells with RA or removal of $\gamma \delta \mathrm{T}$ cells from a bulk population of T cells significantly reduced their capacity to induce EAE, demonstrating a critical role for $\gamma \delta$ T cells in promoting pathogenic Th17 cells. Our findings demonstrate that the anti-inflammatory properties of RA are mediated in part by suppressing STAT3-mediated activation of cytokine production and cytokine receptor expression in $\gamma \delta$ T cells, which suppresses their ability to activate Th17 cells.
\end{abstract} Immunology and Cell Biology (2016) 94, 763-773; doi:10.1038/icb.2016.39

At the border between innate and adaptive immunity, $\gamma \delta \mathrm{T}$ cells express T-cell receptor (TCR) that recognize non-major histocompatibility complex-restricted antigens, but also express receptors for cytokines and Toll-like receptors. These cells are rapidly activated upon inflammation, stress or infection, provide early sources of cytokines such as IFN- $\gamma$, IL-17 and IL-21, and enhance immune responses, for instance by influencing antigen-specific $\mathrm{CD} 4^{+} \mathrm{T}$ cells. ${ }^{1-3}$ In experimental autoimmune encephalomyelitis (EAE), a mouse model for multiple sclerosis (MS), the role of $\gamma \delta \mathrm{T}$ cells, and particularly of IL-17-producing $\gamma \delta \mathrm{T}$ cells has been the subject of debate, although the consensus view is that they have a pathogenic role in this disease. ${ }^{1,4-6} \gamma \delta \mathrm{T}$ cells secrete IL-17 in response to stimulation with IL-23 and IL-1 $\beta$, IL- $1 \alpha$ or IL-18, without TCR engagement. ${ }^{3,7}$ During development of EAE, IL- $17^{+} \gamma \delta \mathrm{T}$ cells and in particular the $\mathrm{V} \gamma 4$ subtype of $\gamma \delta \mathrm{T}$ cells are the first cells to produce IL-17 and are found at high numbers in the brains of the mice early in the course of disease. $^{2,3,8}$ Moreover, mice lacking functional $\gamma \delta \mathrm{T}$ cells $\left(\mathrm{TCR}^{-1-}\right.$ mice) have delayed and attenuated EAE and the production of IL-17A by autoantigen-specific Th17 cells is reduced in these mice, indicating that $\gamma \delta \mathrm{T}$ cells enhance the pathogenicity of $\mathrm{CD}^{+} \mathrm{T}$ cells in this model. ${ }^{3,9}$ Activated $\gamma \delta \mathrm{T}$ cells also antagonize the anti-inflammatory activity of regulatory $\mathrm{T}$ (Treg) cells and inhibit their differentiation, thereby enhancing the activity of effector $\mathrm{T}$ cells that mediate the development of EAE. ${ }^{2}$

Retinoic acid (RA), the active metabolite of vitamin A, is a powerful immunomodulator, which, in the steady state, promotes immune tolerance by enhancing Foxp $3^{+}$Treg cells and inhibiting the differentiation of Th17 cells. ${ }^{10}$ However, in inflammatory conditions, RA can promote effector Th1 and Th17 and thereby enhance inflammation. ${ }^{11,12}$ AM80, a selective agonist of the RA nuclear receptor- $\alpha(\mathrm{RAR} \alpha)$ has been shown to have a protective effect in the early stages of EAE by inhibiting the differentiation of pathogenic Th17 cells. ${ }^{12-15}$ Administered at later stages of the disease, AM80 delays the recovery from EAE by inducing the apoptosis and differentiation of immature myeloid-derived suppressor cells, a cell population that exerts immunosuppressive effects on effector T cells. ${ }^{16}$ RA has also been shown to protect mice from EAE by inhibiting the maturation of dendritic cells and monocytes thereby impairing their antigen presentation function. ${ }^{17}$

We have previously reported that RA has a protective effect in a mouse model of colitis by promoting IL-22 production by $\gamma \delta \mathrm{T}$ cells and type 3 innate lymphoid cells (ILC3). ${ }^{18}$ Given the important role of IL-17A-producing $\gamma \delta$ T cells in the development of EAE, we addressed the hypothesis that RA may be protective in EAE through modulating the function of $\gamma \delta \mathrm{T}$ cells. We found that RA significantly inhibited

${ }^{1}$ Immune Regulation Research Group, School of Biochemistry and Immunology, Trinity Biomedical Sciences Institute, Trinity College Dublin, Dublin, Ireland and ${ }^{2}$ Department of Biology, Maynooth University, Maynooth, Kildare, Ireland

Correspondence: Professor KHG Mills, Immune Regulation Research Group, School of Biochemistry and Immunology, Trinity Biomedical Sciences Institute, Trinity College Dublin, Dublin 2, Ireland.

E-mail: kingston.mills@tcd.ie

Received 2 February 2016; revised 12 April 2016; accepted 13 April 2016; accepted article preview online 19 April 2016 ; advance online publication, 10 May 2016 
a

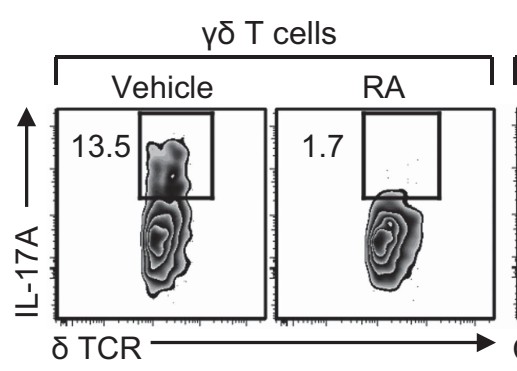

$\mathrm{CD}^{+} \mathrm{T}$ cells

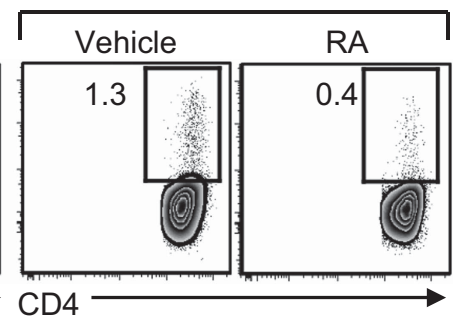

b

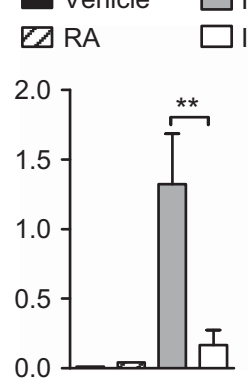

IL1- $\beta+$ IL-23

$L 1-\beta+I L-23+R A$

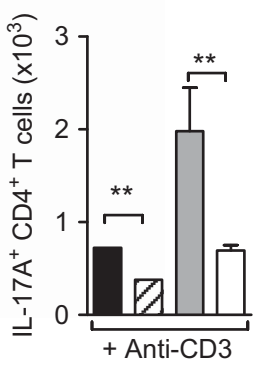

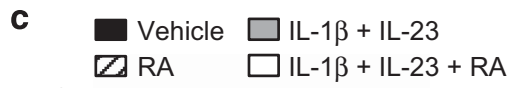

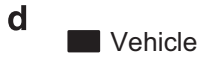

IL-1 + IL-23 $\square$ IL-1 $\beta$ + IL-23 + RA
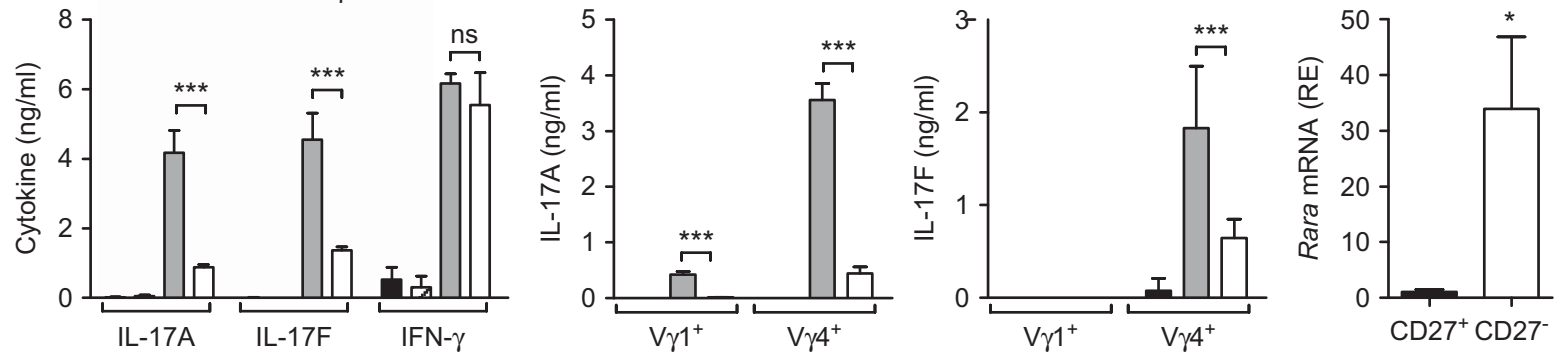

f
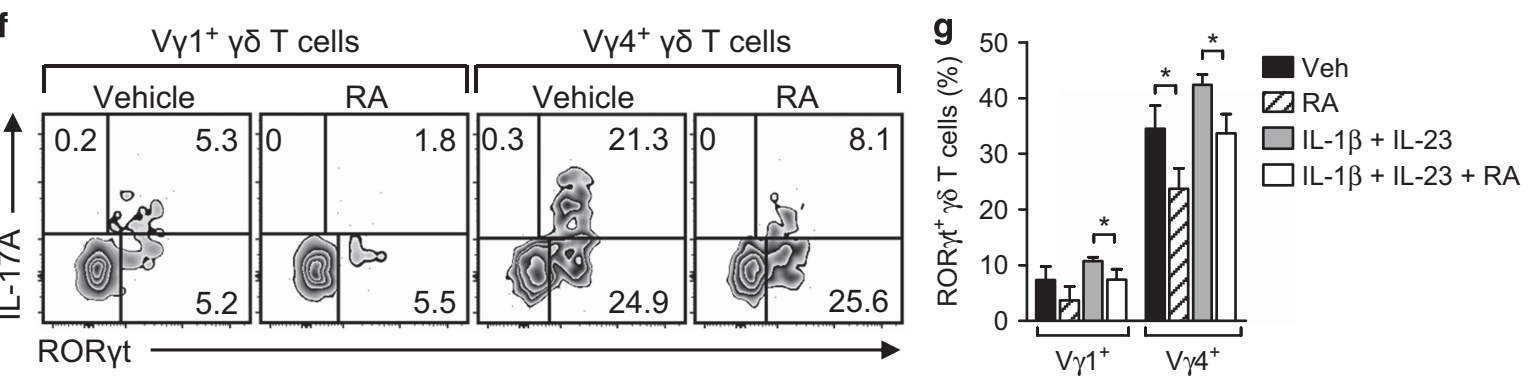

Figure 1 RA impairs IL-17A but not IFN- $\gamma$ production by $\gamma \delta$ T cells and $\mathrm{CD}^{+} \mathrm{T}$ cells. (a, b) Spleen cells from naive mice were cultured for 3 days with medium or anti-CD3 and in combination with IL-1 $\beta$ and IL-23 and in the presence or absence of RA. (a) Representative FACS plots of IL-17A expression by $\gamma \delta \mathrm{T}$ cells and $\mathrm{CD}^{+} \mathrm{T}$ cells. (b) Mean absolute numbers of IL-17A ${ }^{+}$and IFN- $\gamma^{+} \gamma \delta \mathrm{T}$ cells and $\mathrm{CD} 4^{+} \mathrm{T}$ cells in the cultures. (c-f) $\gamma \delta \mathrm{T}$ cells purified from lymph nodes of naive mice were cultured for 3 days with IL-1 $\beta+$ IL-23, with or without RA. (c) IL-17A, IL-17F and IFN- $\gamma$ concentration measured by ELISA in the supernatants of purified $\gamma \delta$ T cells cultured for 3 days with IL-1 $\beta+$ IL-23, with or without RA. (d) IL-17A and IL-17F concentration measured by ELISA in the supernatants of purified $V_{\gamma} 1^{+}$or $V_{\gamma} 4^{+} \gamma \delta$ T cells cultured for 3 days with IL-1 $\beta+I L-23$, with or without RA. (e) Relative expression of rara in CD27 $7^{+}$and CD27- $\gamma \delta$ T cells purified by FACS. (f, g) Representative FACS plots (f) and mean frequencies (g) of $V_{\gamma} 1^{+}$and $V_{\gamma} 4^{+} \mathrm{T}$ cells expressing IL-17A and ROR $\gamma t$ after 3 days of culture with IL-1 $\beta+\mathrm{IL}-23$, with or without RA. Data are representative of three independent experiments. Bars are mean+s.d.; ${ }^{*} P<0.05$, $* * P<0.01$ and $* * * P<0.001$, two-tailed unpaired t-test.

IL-17A and IL-17F production by $\gamma \delta \mathrm{T}$ cells and $\mathrm{CD} 4^{+} \mathrm{T}$ cells stimulated with IL-1 $\beta$ and IL-23, but the effect on $\gamma \delta \mathrm{T}$ cells was more dramatic. Furthermore, treatment of $\gamma \delta \mathrm{T}$ cells with RA significantly inhibited the capacity of $\mathrm{T}$ cells from myelin oligodendrocyte glycoprotein (MOG)-immunized mice to induce EAE by adoptive transfer. In addition, RA impaired the differentiation of IL-17A-expressing $\gamma \delta \mathrm{T}$ cells by inhibiting ROR $\gamma \mathrm{t}$ expression and downregulating expression of receptors for IL-1 $\beta$ and IL-23.

\section{RESULTS}

RA inhibits IL-17 production by $\gamma \delta \mathrm{T}$ cells in vitro and in vivo We have previously demonstrated that $\gamma \delta$ T cells secrete IL-17 and IFN- $\gamma$ following stimulation with IL- $1 \beta$ and IL-23 without TCR activation, whereas $\mathrm{CD}^{+}$memory $\mathrm{T}$ cells secrete IL-17 following stimulation with IL-1 $\beta$ and IL-23 in the presence of anti-CD3. ${ }^{3,19}$ Here, we examined the effect of RA on cytokine production by $\gamma \delta$ T cells. We found that RA suppressed IL-17 production by both $\gamma \delta$
$\mathrm{T}$ cells within a bulk population of spleen cells stimulated with IL-1 $\beta$ and IL-23 (Figures 1a and b). IL-1 $\beta$ and IL-23 also induced IL-17 production by $\mathrm{CD}^{+} \mathrm{T}$ cells but only when co-stimulated with antiCD3 and this was also inhibited by co-culture with RA (Figures 1a and $\mathrm{b})$. We then examined the effect of RA on purified $\gamma \delta \mathrm{T}$ cells or $\mathrm{V} \gamma 1^{+}$or $\mathrm{V} \gamma 4^{+} \gamma \delta \mathrm{T}$ cells from lymph nodes of naive mice. Stimulation of $\gamma \delta \mathrm{T}$ cells with RA alone did not change basal cytokine production (Figure 1c). Stimulation of $\gamma \delta$ T cells with IL- $1 \beta$ and IL-23 induced high concentrations of IL-17A and IL-17F, mainly by ${\mathrm{V} \gamma 4^{+}}^{+} \mathrm{T}$ cells (Figures 1c-e), as well as IFN- $\gamma$ (Figure 1c). The addition of RA significantly reduced the production of IL-17A and IL-17F (Figures 1c, $\mathrm{d}$ and $\mathrm{f}$ ). In contrast, RA did not affect the production of IFN- $\gamma$ by $\gamma \delta$ T cells (Figure 1c and data not shown). The expression of the nuclear receptor for RA, RAR $\alpha$, was 34 times higher in the IL-17-producing $\gamma \delta$ $\mathrm{T}$ cells $\left(\mathrm{CD} 27^{-}\right)$when compared with $\gamma \delta \mathrm{T}$ cells that express IFN- $\gamma$ $\left(\mathrm{CD} 27^{+}\right)$(Figure 1e). Interestingly, the expression of the transcription factor ROR $\gamma \mathrm{t}$, required for the production of IL-17, was impaired by 
RA in $\gamma \delta \mathrm{T}$ cells stimulated or not with IL-1 $\beta$ and IL-23, and particularly in ${\mathrm{V} \gamma 4^{+}}^{\mathrm{T}} \mathrm{T}$ cells (Figures if and $\mathrm{g}$ ).

We next assessed the effect of RA on cytokine production by $\gamma \delta$ $\mathrm{T}$ cells and $\mathrm{CD}^{+} \mathrm{T}$ cells in vivo. The production of IL-17A by $\gamma \delta$ $\mathrm{T}$ cells was strongly inhibited in mice injected with RA when compared with mice injected with vehicle (Figures $2 \mathrm{a}$ and $\mathrm{b}$ ). The production of IL-17A by $\mathrm{CD} 4^{+} \mathrm{T}$ cells was also affected in the mice injected with RA but to a lesser extent when compared with the effect on $\gamma \delta \mathrm{T}$ cells (Figures 2a and b). In contrast, RA did not affect the production of IFN- $\gamma$ by $\gamma \delta \mathrm{T}$ cells or $\mathrm{CD} 4^{+} \mathrm{T}$ cells (Figure $2 \mathrm{~b}$ ).

\section{RA inhibits IL-17 production by CD4 and $\gamma \delta$ T cells from mice with} EAE

IL-17A-producing $\gamma \delta \mathrm{T}$ cells and CD4 ${ }^{+} \mathrm{T}$ cells (Th17 cells) have been shown to have pathogenic roles in a range of autoimmune diseases, including MS and EAE where they promote inflammation. It has previously been reported that retinoids can attenuate development of EAE. ${ }^{15,17}$ However, these studies did not examine the effect of RA on $\gamma \delta \mathrm{T}$ cells. Having shown that RA impairs IL-17A production mainly by $\gamma \delta \mathrm{T}$ cells but also by $\mathrm{CD}^{+}{ }^{+} \mathrm{T}$ cells, we examined its effect on $\gamma \delta$ $\mathrm{T}$ cells and $\mathrm{CD} 4^{+} \mathrm{T}$ cells from mice with EAE. Mice were immunized with the myelin antigen MOG emulsified in complete Freund's adjuvant and 10 days later their spleens and draining lymph nodes

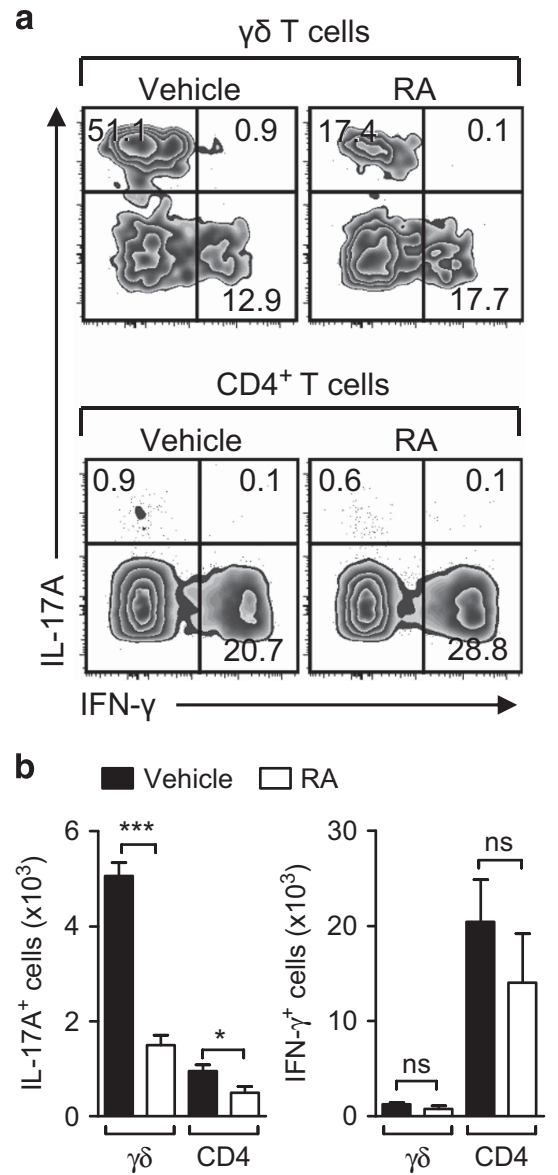

Figure 2 RA inhibits IL-17 production by $\gamma \delta \mathrm{T}$ cells and $\mathrm{CD}^{+}{ }^{+} \mathrm{T}$ cells in vivo. (a, b) Representative FACS plots (a) and absolute numbers (b) of IL-17A and IFN $-\gamma^{+} \gamma \delta \mathrm{T}$ cells and $\mathrm{CD}^{+} \mathrm{T}$ cells isolated from peritoneal cavity $18 \mathrm{~h}$ after injection of RA or vehicle only (dimethyl sulfoxide) and re-stimulation with phorbol 12-myristate 13-acetate, ionomycin and brefeldin A. Bars are mean +s.e.m.; ${ }^{*} P<0.05$ and ${ }^{* * *} P<0.001$, two-tailed unpaired $t$-test. cells were isolated and cultured with MOG, IL-1 $\beta$ and IL-23 to drive the differentiation of IL-17-producing $\gamma \delta$ T cells and Th17 cells, and in the presence of RA or vehicle control. The production of IL-17A, IL-17F and IFN- $\gamma$ measured in the supernatant of the cultures by ELISA was strongly attenuated by addition of RA (Figure 3a). We next examined more closely the effect of RA on cytokine production by $\gamma \delta$ $\mathrm{T}$ cells and $\mathrm{CD}^{+} \mathrm{T}$ cells using intracellular cytokine staining and fluorescence-activated cell sorting (FACS) analysis (Figures $3 \mathrm{~b}$ and c) or by RT-PCR performed on $\gamma \delta \mathrm{T}$ cells and $\mathrm{CD}^{+} \mathrm{T}$ cells sorted at the end of the culture (Figure 3d). We found that RA inhibited IL-17A principally in $\gamma \delta \mathrm{T}$ cells and particularly in the $\mathrm{V} \gamma 4^{+} \gamma \delta \mathrm{T}$ cells, but also in $\mathrm{CD}^{+} \mathrm{T}$ cells (Figures $3 \mathrm{~b}-\mathrm{d}$ ). The expression of IL-17F was also strongly reduced by RA in both $\gamma \delta \mathrm{T}$ cells and $\mathrm{CD}^{+} \mathrm{T}$ cells (Figure 3d). Interestingly, the number of IFN $-\gamma^{+} \gamma \delta \mathrm{T}$ cells was unchanged and the number of IFN $-\gamma^{+} \mathrm{CD} 4^{+} \mathrm{T}$ cells was increased by RA (Figures $3 \mathrm{~b}$ and $\mathrm{c}$ ). However, assessment of other IFN- $\gamma$-producing cell types by FACS indicated that RA impaired IFN- $\gamma$ expression in $\mathrm{CD}^{+} \mathrm{T}$ cells (data not shown). This may explain the overall reduction in IFN- $\gamma$ production detected by ELISA on cultures of mixed LN and spleen cells stimulated with MOG, IL-1 $\beta$ and IL-23 (Figure 3a).

We also assessed the effect of RA on expression of the gene coding for ROR $\gamma$ t by RT-PCR in $\gamma \delta \mathrm{T}$ cells and $\mathrm{CD} 4^{+} \mathrm{T}$ cells purified from the 3-day cultures and found that the expression of rorc was strongly reduced by RA in both cell types (Figure 3e). We also found that the proliferation of $\gamma \delta$ T cells (but not $\mathrm{CD} 4^{+} \mathrm{T}$ cells) and more specifically of the $\mathrm{V} \gamma 4^{+} \gamma \delta \mathrm{T}$ cells was impaired by treatment with RA leading to a reduced number of ${\mathrm{V} \gamma 4^{+}}^{+} \delta \mathrm{T}$ cells in the culture (Figures $3 \mathrm{f}$ and $\mathrm{g}$ and data not shown). Collectively, these findings demonstrated that RA suppresses IL-17 production by $\gamma \delta \mathrm{T}$ cells and Th17 cells and affects the polarization of these cells. Our data also show that RA has the most pronounced inhibitory effect on activation and proliferation of IL-17-secreting $\mathrm{V} \gamma 4^{+} \gamma \delta \mathrm{T}$ cells.

RA suppresses the pathogenic function of $\gamma \delta \mathrm{T}$ cells and $\mathrm{CD} 4^{+}$ $T$ cells in the EAE model

Having shown that RA inhibits IL-17A and IL-17F production principally by $\gamma \delta \mathrm{T}$ cell but also by $\mathrm{CD}^{+} \mathrm{T}$ cells from MOGimmunized mice, we examined the effect of RA on the effector and pathogenic function of these cells in EAE by adoptive transfer to naive mice. Spleen and lymph nodes cells from mice immunized with MOG and complete Freund's adjuvant were cultured under Th17-polarizing conditions (MOG, IL-1 $\beta$ and IL-23) in the presence of RA or a vehicle control. After 3 days, the cells were washed thoroughly and transferred to naive recipient mice $\left(15 \times 10^{6}\right.$ cells per mouse). The mice injected with the vehicle-treated cells developed signs of EAE by day 7 (Figure 4a). In contrast, the onset of EAE was delayed by several days and the clinical signs of disease were strongly attenuated in mice injected with the RA-treated cells (Figure 4a). An examination of infiltrating lymphocytes in the brains of the mice 16 days after the cell transfer revealed that the number of $\mathrm{CD}^{+} \mathrm{T}$ cells infiltrating the brains was greatly reduced in the recipients of the RA-treated cells when compared with the mice injected with the control cells (Figure $4 \mathrm{~b}$ ). Moreover, the number of $\mathrm{CD}^{+} \mathrm{T}$ cells and $\gamma \delta \mathrm{T}$ cells and the production of the cytokines IL-17A, IL-17F, IFN- $\gamma$ and GM-CSF by these cells were significantly lower in the brains of the animals injected with the RA-treated cells when compared with the control group (Figures $4 \mathrm{c}$ and $\mathrm{d}$ ). Thus, RA decreased the production of IFN- $\gamma$, IL-17A and IL-17F induced by IL-1 $\beta$ and IL-23 and particularly the production of IL-17A and IL-17F by $\gamma \delta \mathrm{T}$ cells and Th17 (Figure 3), which resulted in a reduced number of pathogenic $\gamma \delta \mathrm{T}$ cells and $\mathrm{CD} 4^{+}$ 

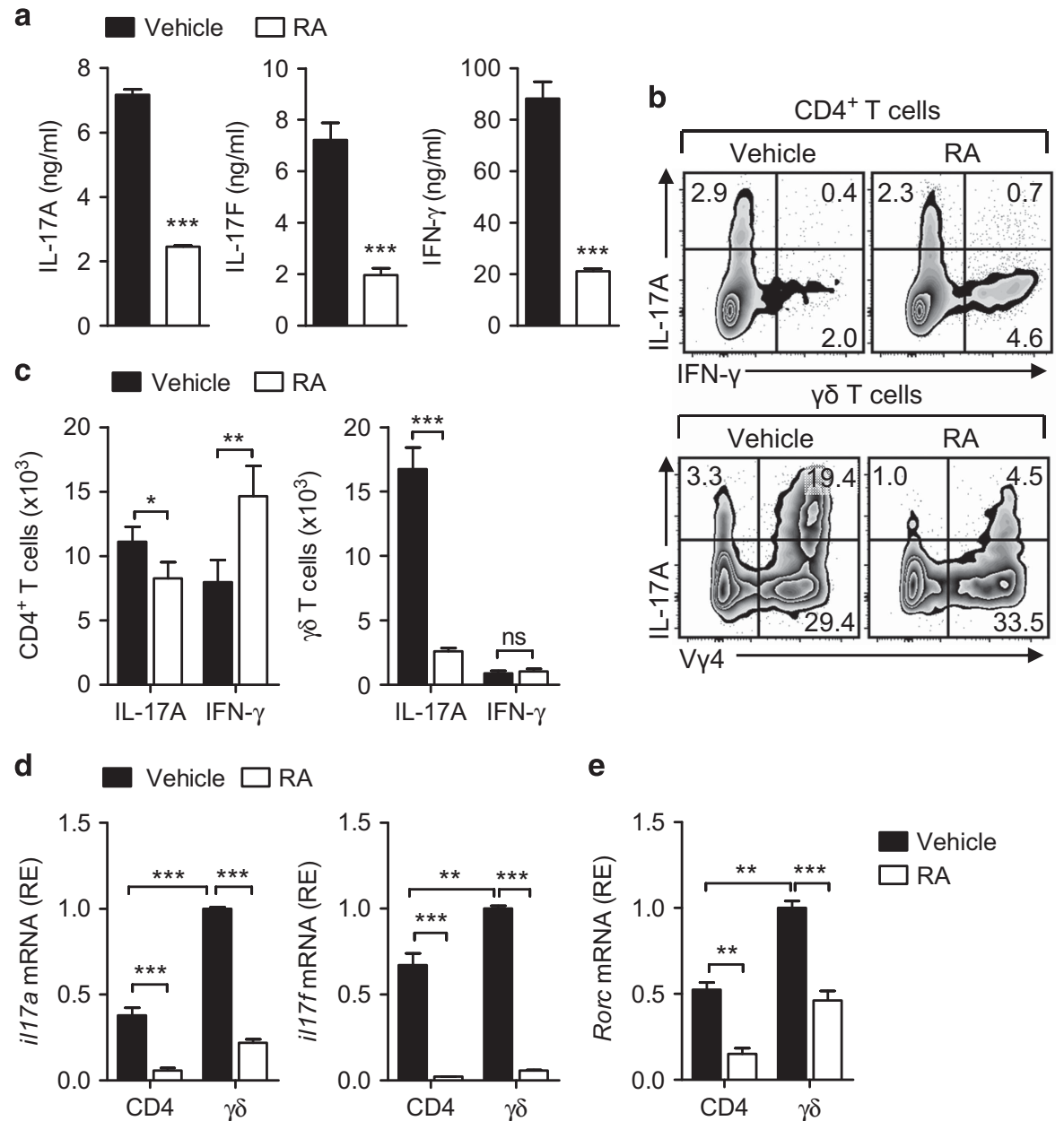

\section{f}
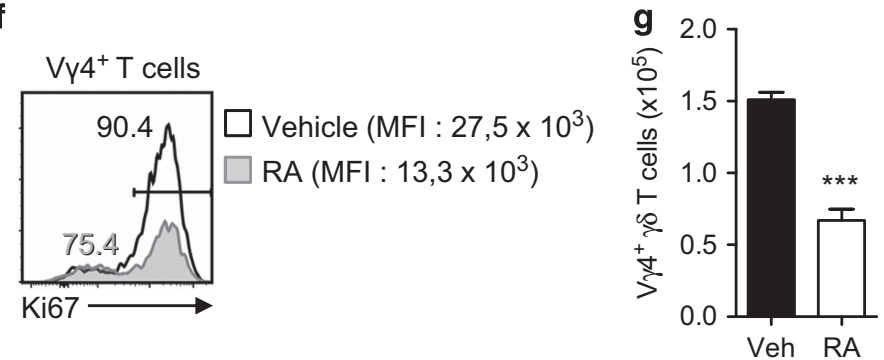

Figure 3 RA suppresses IL-17 production and RORyt expression in $\mathrm{CD}^{+} \mathrm{T}$ cell and $\gamma \delta \mathrm{T}$ cell and impairs $\mathrm{V} \gamma 4^{+} \mathrm{T}$-cell proliferation under inflammatory conditions. Mice were immunized subcutaneously with MOG emulsified in complete Freund's adjuvant. Ten days after immunization, lymph node and spleen cells were cultured together for 3 days with MOG, IL-1 $\beta$ and IL-23 and either RA or vehicle. (a) IL-17A, IL-17F and IFN- $\gamma$ production was quantified in supernatants by ELISA at the end of the 3 -day culture. (b) Representative FACS plots of the IL- $17 A^{+}$and IFN- $\gamma^{+} \mathrm{CD} 4^{+} \mathrm{T}$ cells and IL- $17 \mathrm{~A}^{+} \mathrm{V} \gamma 4^{+} \gamma \delta \mathrm{T}$ cells at the end of the 3-day culture. (c) Mean absolute numbers of IL-17A+ and IFN- $\gamma^{+} \mathrm{CD} 4^{+} \mathrm{T}$ cells and $\gamma \delta \mathrm{T}$ cells at the end of the 3-day culture. (d, e) Relative expression of $i / 17 a$, ill7f (d) and rorc (e) mRNA measured by RT-PCR on CD4 ${ }^{+} \mathrm{T}$ cells and $\gamma \delta \mathrm{T}$ cells after 3 days of culture. (f) Representative histogram, mean frequencies and mean fluorescence intensity quantifying Ki67 expression in $\mathrm{V}_{\gamma} 4^{+} \mathrm{T}$ cells at the end of the 3-day culture. (g) Absolute number of $\mathrm{V} \gamma 4^{+} \gamma \delta \mathrm{T}$ cells after 3 days of culture. Bars are mean+s.d. ${ }^{*} P<0.05,{ }^{* *} P<0.01$ and ${ }^{* * *} P<0.001$ (two-tailed unpaired $t$-test).

$\mathrm{T}$ cells infiltrating the brains and a consequent attenuation of the clinical signs of EAE (Figure 4).

RA mediates immunomodulatory activity largely through its effect on $\gamma \delta \mathrm{T}$ cells

As the impact of RA seemed particularly striking on $\gamma \delta \mathrm{T}$ cells (Figures 1,2 and 3), we examined more closely the effect of RA on the pathogenic function of these cells. We first evaluated the importance of $\gamma \delta$ T cells in our EAE model by performing an adoptive transfer of cells from MOG-immunized mice depleted of $\gamma \delta \mathrm{T}$ cells. Spleen and lymph nodes cells from mice immunized with MOG and complete Freund's adjuvant were depleted of $\gamma \delta \mathrm{T}$ cells, or left un-separated, before being stimulated for 3 days in Th17-polarizing conditions and then transferred to recipient animals. Depletion of $\gamma \delta \mathrm{T}$ cells prior to culture reduced the production of IL-17A, IL-17F and IFN- $\gamma$ by the spleen and lymph node cells (Figure 5a). Intracellular cytokine staining and FACS showed that depletion of $\gamma \delta$ T cells prior to culture impaired the expansion of Tbet $^{+}$and $\mathrm{ROR} \gamma \mathrm{t}^{+} \mathrm{CD} 4^{+} \mathrm{T}$ cells (Th1 and 
a

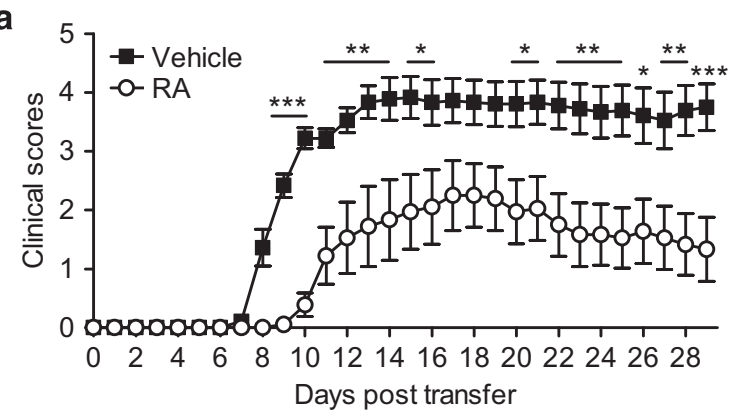

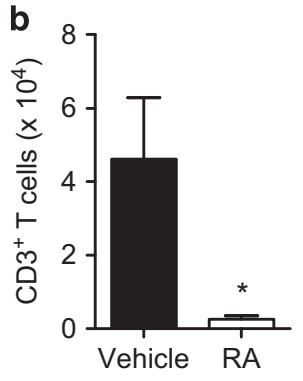

үठ T cells

C
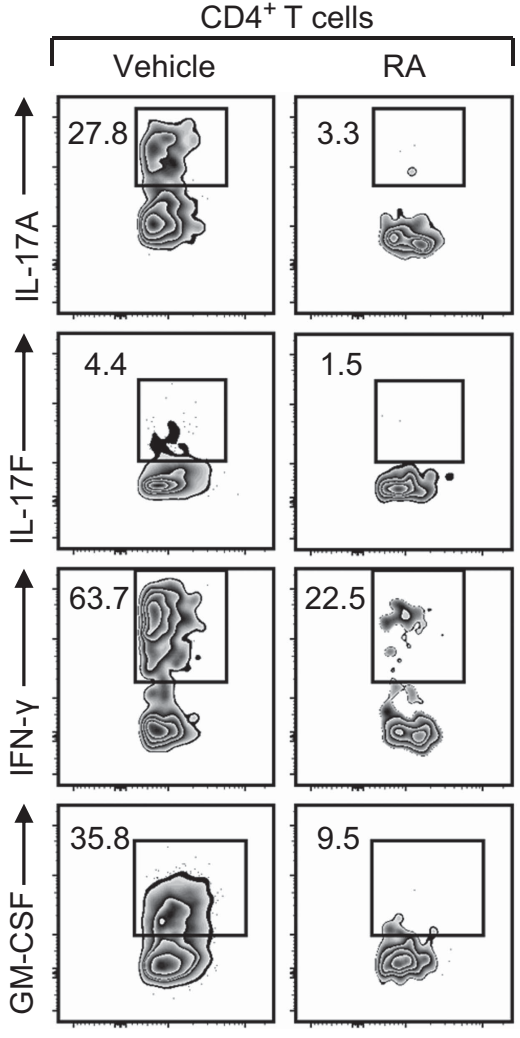

CD3
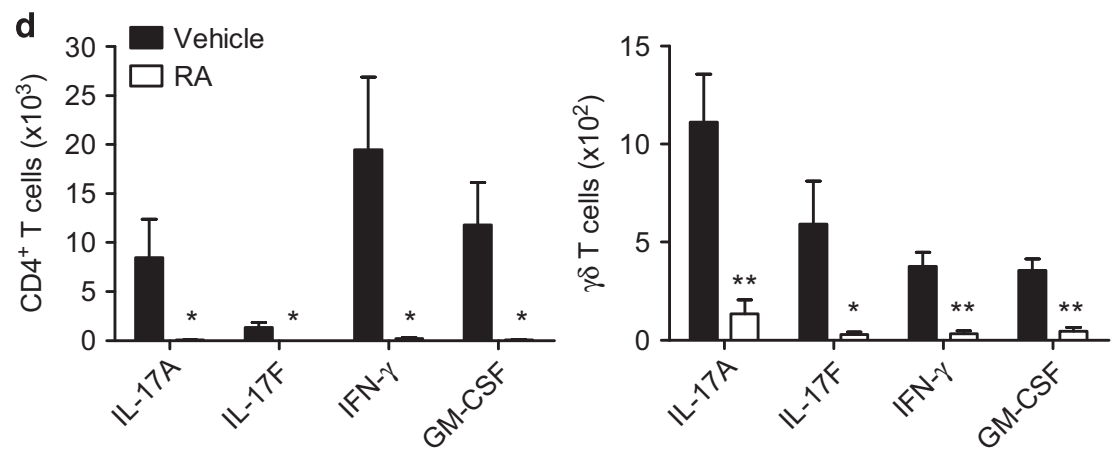

Figure 4 Treatment of T cells from MOG-immunized mice with RA suppresses their ability to induce EAE by adoptive transfer. Donor mice were immunized with MOG+complete Freund's adjuvant and after 10 days, spleen and lymph node cells were cultured for 3 days with MOG, IL-1 $\beta+$ IL-23 and RA or vehicle and then $15 \times 10^{6}$ cells were transferred to naive mice. (a) EAE clinical scores in recipient mice. (b) Absolute number of $\mathrm{CD}^{+} \mathrm{T}$ cells detected in the brains

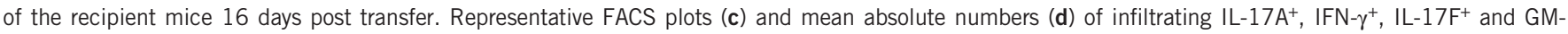
$\mathrm{CSF}^{+} \mathrm{CD}^{+}$and $\gamma \delta \mathrm{T}$ cells in the brains of the recipient mice 16 days post transfer and re-stimulated ex vivo for $5 \mathrm{~h}$ with phorbol 12-myristate $13-a c e t a t e$, ionomycin and brefeldin A. Data are representative of three independent experiments. Data shown as mean \pm s.e.m. (a) or mean + s.e.m. (b, d) and statistics were calculated using a two-way analysis of variance with Bonferroni post-test (a) or two-tailed unpaired $t$-test (b-d). ${ }^{*} P<0.05,{ }^{* *} P<0.01$ and ${ }^{* * *} P<0.001$. 


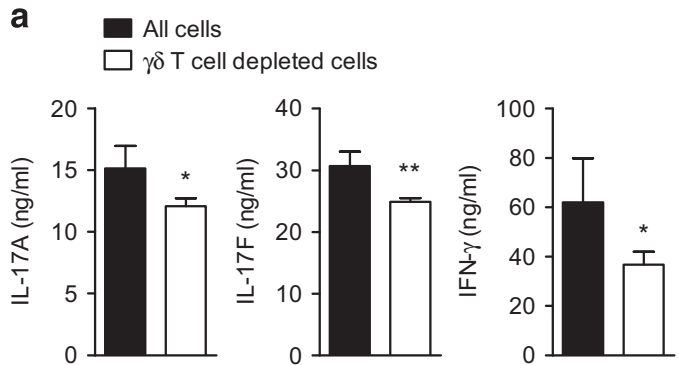

b

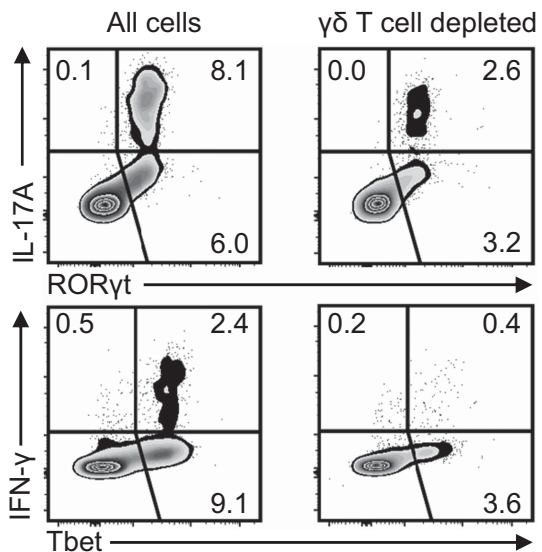

C

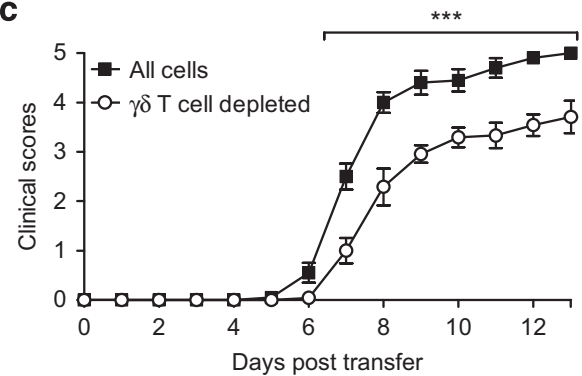

Figure 5 Depletion of $\gamma \delta \mathrm{T}$ cells attenuates EAE induced by T-cell transfer. Spleen and lymph node cells from MOG-immunized mice were depleted of $\gamma \delta \mathrm{T}$ cells or un-depleted. Cells were cultured for 3 days with MOG, IL-1 $\beta$ +IL-23, and then $15 \times 10^{6}$ cells were transferred to naive mice. (a) IL-17A, IL-17F and IFN- $\gamma$ concentration measured by ELISA in supernatants the cultures after 3 days. (b) Representative FACS plots of IL-17A, ROR $\gamma \mathrm{t}$, IFN- $\gamma$ and Tbet expression in $T$ helper cells at the end of the 3-day culture. (c) EAE clinical scores of recipient mice. Data are representative of two independent experiments and are shown as mean+s.d. (a) or mean \pm s.e.m. (c). Statistics were calculated using two-tailed unpaired $t$-test (a) or a two-way analysis of variance with Bonferroni post-test (c). ${ }^{*} P<0.05$, ${ }^{* *} P<0.01$ and ${ }^{* * *} P<0.001$

Th17 cells, respectively) and attenuated their ability to produce IFN- $\gamma$ and IL-17A, respectively (Figure 5b). Finally, we found that removal of $\gamma \delta \mathrm{T}$ cells prior to in vitro re-stimulation of MOG-primed T cells significantly impaired the ability of these $\mathrm{T}$ cells to induce EAE when transferred to naive mice (Figure $5 \mathrm{c}$ ). These results indicate that $\gamma \delta$ $\mathrm{T}$ cells contribute to the polarization of both Th1 and Th17 cells, reflected in their reduced pathogenic activity in the EAE model.

We next examined whether the attenuating effects of RA on induction of EAE by cell transfer could be mediated directly through its effect on $\gamma \delta \mathrm{T}$ cells. Thus, we isolated spleen and draining lymph node cells from MOG-immunized mice and separated them into $\gamma \delta$ $\mathrm{T}$ cells and $\gamma \delta$ T-cell-depleted fractions. The $\gamma \delta$ T cells were stimulated for $6 \mathrm{~h}$ with IL-1 $\beta$ and IL-23, in the presence of RA or its vehicle, before being washed thoroughly and cultured with the $\gamma \delta$ T-celldepleted fraction. The combined cells were then cultured with IL-1 $\beta$, IL-23 and MOG for 3 days and transferred to recipient mice. Prior to transfer, we examined the cytokine profile in the supernatants at the end of the 3-day culture. Consistent with the treatment of all the cells with RA, treatment of only the $\gamma \delta \mathrm{T}$ cells with RA resulted in a significant reduction of IL-17A and IL-17F production (Figure 6a). FACS analysis of the cells at the end of the 3-day culture revealed that IL-17A expression was significantly impaired in $\gamma \delta \mathrm{T}$ cells and principally in the ${\mathrm{V} \gamma 4^{+}}^{+} \delta \mathrm{T}$ cells, which constituted the main IL-17A producers among $\gamma \delta \mathrm{T}$ cells in our model (Figures $6 \mathrm{c}$ and $\mathrm{d}$ ). Interestingly, the production of IFN- $\gamma$ was not affected by the RA-treated $\gamma \delta \mathrm{T}$ cells (Figure $6 \mathrm{c}$ and data not shown).

We next examined the effect of RA-treated $\gamma \delta \mathrm{T}$ cells on the capacity of MOG-specific T cell to induce EAE by adoptive transfer. Transfer of cells cultured with the vehicle-treated $\gamma \delta \mathrm{T}$ cells to naive mice induced EAE by day 6 in these mice (Figure $6 \mathrm{~d}$ ). In contrast, the onset of the disease was delayed and the severity of the symptoms was significantly reduced in recipients of the MOG-specific cells containing the RA-treated $\gamma \delta \mathrm{T}$ cells (Figure $6 \mathrm{~d}$ ). The frequency and absolute number of $\mathrm{CD}^{+} \mathrm{T}$ cells producing IL-17A, IFN- $\gamma$ and GM-CSF was reduced in the brains of the mice injected with the cells containing RA-treated $\gamma \delta \mathrm{T}$ cells (Figures 6e and $\mathrm{f}$ and data not shown). Taken together, our findings provide further evidence of a pathogenic role for $\gamma \delta \mathrm{T}$ cells in central nervous system autoimmunity, and demonstrate that treatment of these cells with RA impairs their IL-17A production, especially by the $\mathrm{V} \gamma 4^{+}$subtype, which results in significant attenuation of their pathogenic function in vivo.

RA inhibits the IL-1 $\beta$ and IL-23 pathway in $\gamma \delta \mathrm{T}$ cells

We investigated the mechanisms by which RA modulates activation of $\gamma \delta \mathrm{T}$ cells. We first assessed the effect of RA on $\gamma \delta \mathrm{T}$ cells purified from naive mice. We found that, within $3 \mathrm{~h}$ of culture with IL-1 $\beta$ and IL-23, RA inhibited the expression of the receptors subunits for IL-1 $\beta$ and IL-23, which transduce the signals to promote IL-17A and IL-17F expression in $\gamma \delta \mathrm{T}$ cells (Figure 7a). Interestingly, stimulation of purified $\gamma \delta \mathrm{T}$ cells with IL-12 and IL-18, which are more potent stimuli for IFN- $\gamma$ production, induced low concentration of IL-17A, which was significantly enhanced by RA, while the production of IL-17A induced by IL-1 $\beta$ and IL-23 was inhibited by RA (Figures 7b and c). In contrast, RA did not affect IFN- $\gamma$ production by purified $\gamma \delta$ $\mathrm{T}$ cells stimulated with IL-12 and IL-18 or IL-1 $\beta$ and IL-23 (Figure $7 \mathrm{~b}$ ). Moreover, RA did not impair IL-17 production by $\mathrm{CD}^{+} \mathrm{T}$ cells and $\gamma \delta \mathrm{T}$ cells in cultures of spleen and LN cells stimulated with MOG alone (Figure 7d). We then examined the effect of RA on expression of illr1 and il23r on purified $\gamma \delta \mathrm{T}$ cells from MOG-immunized mice. The results revealed that RA inhibited the expression of illr1 and $i l 23 r$ in $\gamma \delta \mathrm{T}$ cells and principally in the $\mathrm{V}_{\gamma} 4^{+}$ $\gamma \delta \mathrm{T}$-cell subset (Figures $7 \mathrm{e}$ and $\mathrm{f}$ ) and dramatically reduced the number of $\mathrm{V} 4^{+} \gamma \delta \mathrm{T}$ cells expressing cell surface receptors for IL-1 $\beta$ and IL-23 (Figure $7 \mathrm{~g}$ ). The activation of the IL-1 $/ \mathrm{IL}-23$ pathway is known to involve the phosphorylation of STAT3, which induces Th17-type cytokine in IL-17-producing cells. ${ }^{20}$ We found that treatment of cells from MOG-immunized mice with RA inhibited STAT3 phosphorylation (Figure 7h). Taken together, our data demonstrate that RA affects the expression of the receptors for IL- $1 \beta$ and IL-23 at the surface of $\gamma \delta \mathrm{T}$ cells, resulting in an impaired response of these cells to IL-1 $\beta$ and IL-23. 


\section{DISCUSSION}

In this study, we demonstrate that RA significantly inhibits the function of IL-17A-producing $\gamma \delta$ T cells, impairing their proliferation, cytokine production and their pathogenic activity in vivo in the EAE model. In addition, we show that under steady state conditions and during inflammation, RA also inhibits cytokine production by Th17 cells, which are considered to be the primary pathogenic $\mathrm{T}$ cells in EAE and other autoimmune diseases. Our findings suggest that a significant component of the attenuating effect of RA in immunemediated disease is mediated through its effect on $\gamma \delta \mathrm{T}$ cells and in
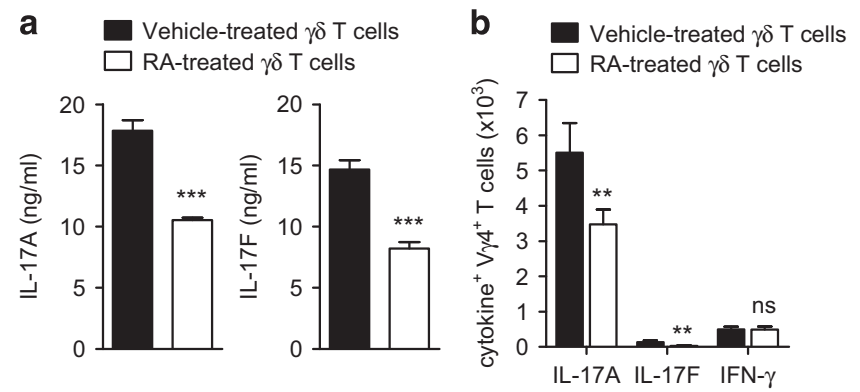

C

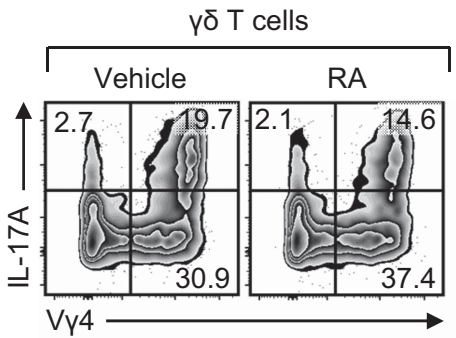

d $\rightarrow$ Vehicle-treated $\gamma \delta$ T cells -0 RA-treated $\gamma \delta$ T cells

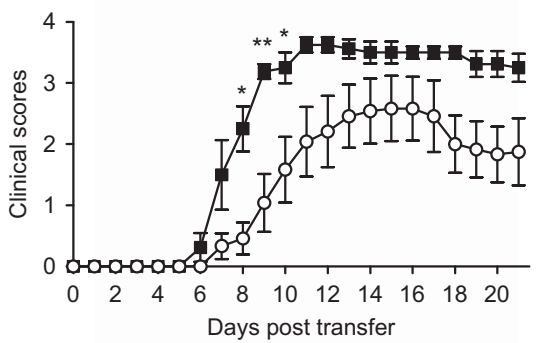

e
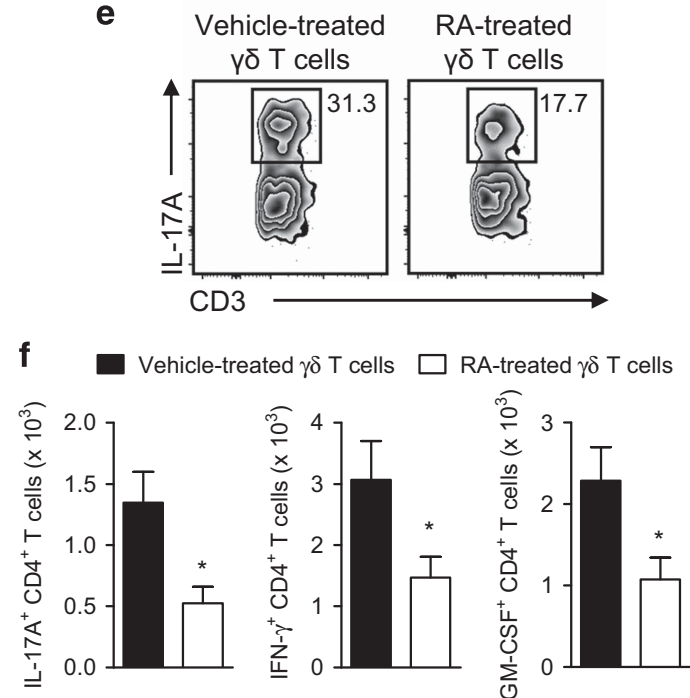

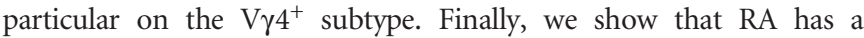
selective suppressive effect on IL-17A and IL-17F production by $\gamma \delta$ T cells, with little effect on IFN- $\gamma$, which is explained by its inhibitory effect on the IL-1 $1 \beta /$ IL-23 signaling pathway.

Following the discovery of Th17 cells, these cells have become the main focus of attention as mediators of pathology in many autoimmune diseases, including EAE-a mouse model for MS. ${ }^{21,22}$ Indeed, IL- $17 \mathrm{~A}^{-1-}$ mice are resistant to the development of EAE and the administration of anti-IL-17A-neutralizing antibody during the early stages of EAE delays the onset of the symptoms. ${ }^{23,24}$ However, $\gamma \delta$ $\mathrm{T}$ cells have also been shown to be an important source of IL-17A and to have a key pathogenic role in EAE. ${ }^{3}$ Previous studies on the effect of RA on IL-17-producing $\mathrm{T}$ cells have focused on $\mathrm{CD}^{+} \mathrm{T}$ cells; it has been reported that AM80, a RAR $\alpha$ agonist, inhibits IL-17 production by Th17 cells. ${ }^{15}$ However, this and other studies on the effect of RA or vitamin A deficiency did not examine the effect on $\gamma \delta \mathrm{T}$ cells. We report that RA has a potent inhibitory effect on IL-17 production by $\gamma \delta \mathrm{T}$ cells and in particular on the $\mathrm{V} \gamma 4^{+}$subtype that is pathogenic in EAE. $\mathrm{V} \gamma 4 \mathrm{~V} \delta 4^{+}$cells are the main IL-17-producing- $\gamma \delta$ T-cell subtype in a model of collagen-induced arthritis. ${ }^{25}$ Although we did not examine $V \gamma 4^{+} \mathrm{V} \delta 4^{+}$, we did examine the effect of RA on purified $\mathrm{V} \gamma 4^{+}$and $\mathrm{V} \gamma 1^{+}$cells and while $\mathrm{V} \gamma 4^{+}$were the predominant IL-17 producing cells, IL-17 production by both subtypes was inhibited by RA. Importantly, we demonstrated that RA had a greater effect on IL-17-producing $\gamma \delta \mathrm{T}$ cells than Th17 cells. One explanation for this observation may be that when compared with Th17 cells, IL-17-producing $\gamma \delta \mathrm{T}$ cells respond very quickly and strongly to the inflammatory cytokines IL- $1 \beta$ and IL-23 (inhibited by RA), without a need of TCR stimulation. It is also possible that IL-17-producing $\gamma \delta$ $\mathrm{T}$ cells may express higher levels of nuclear receptors for RA.

We and others have previously reported that $\gamma \delta \mathrm{T}$ cells are an important source of IL-17 and related cytokines in the development of EAE and have demonstrated that $\gamma \delta \mathrm{T}$ cells as well as producing early IL-17 also promote activation of Th17 cells. ${ }^{3,5,8}$ Consistent with these findings, the present study demonstrates that the differentiation of Th17 and Th1 cells and the production of their associated cytokines IL-17A, IL-17F and IFN- $\gamma$ are impaired when $\gamma \delta \mathrm{T}$ cells are depleted from spleen and lymph node cells from MOG-immunized mice and stimulated in vitro with MOG, IL-1 $\beta$ and IL-23. Thus, the reduction in

Figure 6 Selective treatment of $\gamma \delta$ T cells with RA decreases the production of IL-17A and IL-17F during EAE and alters the capacity of T cells from MOG-immunized mice to induce EAE by cell transfer. Spleen and lymph node cells from MOG-immunized mice were isolated and the $\gamma \delta \mathrm{T}$ cells purified and cultured separately with RA or its vehicle for $6 \mathrm{~h}$ before being put back in culture with the rest of the cells. The total cells containing either the vehicle- or the RA-treated $\gamma \delta \mathrm{T}$ cells were then cultured with MOG, IL-1 $\beta$ and IL-23. After 3 days of culture, $10 \times 10^{6}$ cells were transferred to naive mice. (a) IL-17A and IL-17F expression as measured by ELISA in the supernatants at the end of the 3-day culture. (b) Mean absolute numbers of IL-17A $\mathrm{A}^{+}, \mathrm{IL}-17 \mathrm{~F}^{+}$and IFN- $\gamma^{+} \mathrm{V}_{\gamma} 4^{+} \gamma \delta \mathrm{T}$ cells at the end of the 3-day culture. (c) Representative FACS plots indicating the proportion

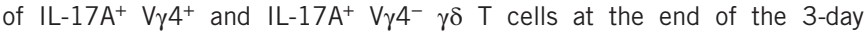
culture. (d) EAE clinical scores of recipient mice. (e) Representative FACS plots indicating the proportion of IL-17A $\mathrm{A}^{+} \mathrm{CD} 4^{+} \mathrm{T}$ cells in the brains of the recipient mice on day 25 post transfer. (f) Absolute numbers of infiltrating IL- $17 A^{+}$, IFN- $\gamma^{+}$and $\mathrm{GM}^{-} \mathrm{CSF}^{+} \mathrm{CD}^{+} \mathrm{T}$ cells in the brains of the recipient mice on day 25 post transfer. Data are representative of two independent experiments. Bars are mean + s.d. (a, b), mean \pm s.e.m. (d) or mean+s.e.m. (f). Statistics are performed as and two-tailed unpaired $t$-test (a-c and $\mathbf{f}$ ) or two-way analysis of variance with Bonferroni post-test (d); ${ }^{*} P<0.05$, ${ }^{* *} P<0.01$ and ${ }^{* * *} P<0.001$. 
pathogenic cytokines observed with RA treatment can be attributed to a combination of a direct effect of RA on IL-17 production by $\gamma \delta$ $\mathrm{T}$ cells and an indirect effect of impaired IL-17 production by $\gamma \delta$ $\mathrm{T}$ cells on Th1- and Th17-cell differentiation. Furthermore, the reduced IFN- $\gamma$ production observed after depletion of $\gamma \delta \mathrm{T}$ cells reflect a removal of IFN- $\gamma$-secreting $\gamma \delta \mathrm{T}$ cells and impaired differentiation of Th1 cells. This is consistent with our demonstration that depletion of $\gamma \delta \mathrm{T}$ cells from the cultures impaired the ability of $\mathrm{T}$ cells to induce EAE when transferred to naive recipient mice. We have previously shown that RA protects against the development of colitis by inducing IL-22 production by both $\gamma \delta$ T cells and ILC3. ${ }^{18}$ Here, we show that in the adoptive transfer model of EAE, while RA reduces cytokine production by Th17 cells, it has a more dramatic effect on $\gamma \delta \mathrm{T}$ cells, impairing their proliferation, ROR $\gamma \mathrm{t}$ expression and production of IL-17A and IL-17F. Recipient mice injected with RA-treated T cells developed very mild EAE with delayed onset when compared with that seen after transfer of untreated cells. Furthermore, central nervous system infiltration of $\mathrm{CD}^{+}$and $\gamma \delta \mathrm{T}$ cells producing IL-17A, IL-17F, GM-CSF and IFN- $\gamma$ was strongly impaired in mice injected with RA-treated cells. Moreover, we demonstrate that the treatment of $\gamma \delta \mathrm{T}$ cells only with RA conferred significant protection against the development of EAE in the recipient mice, and this was associated with a significant decrease in the number of IL-17A, GM-CSF and IFN- $\gamma$ producing $\mathrm{CD}^{+}{ }^{+} \mathrm{T}$ cells infiltrating the brain.

IL-1 $\beta$ and IL-23 are key pathogenic cytokines, which drive the development of many autoimmune diseases. ${ }^{19,21}$ Mice deficient for the IL-1 $\beta$ receptor IL-1R1 or mice lacking the IL-23 subunit IL-23p19 are resistant to induction of EAE. ${ }^{3,26,27}$ Interestingly, we demonstrate that RA directly inhibits the expression of the receptors for IL- $1 \beta$ and IL-23, IL-1R1 and IL-23R respectively, on activated $\gamma \delta \mathrm{T}$ cells in vitro. Finally, we demonstrate that RA impairs the IL-23 pathway by inhibiting phosphorylation of the transcriptional activator of $i l 17 a$ and $i l 17 f$, STAT3. ${ }^{28}$

There is convincing evidence from animal models that Th17 cells and more recently IL-17-secreting $\gamma \delta \mathrm{T}$ cells have crucial pathogenic roles in EAE and other autoimmune diseases. However, the role of IFN- $\gamma$, produced by Th1 cells, $\mathrm{CD}^{+} \mathrm{T}$ cells and NK cells is less clear. ${ }^{29-31}$ Interestingly, we find little effect of RA on IFN- $\gamma$ production by $\mathrm{CD} 4^{+} \mathrm{T}$ cells or even when $\gamma \delta \mathrm{T}$ cells are cultured with IL-12 and IL-18, the classical stimuli for IFN- $\gamma$ production.

It has been reported that RA synergizes with TGF- $\beta$ to induce Treg cells, especially in the gut in a steady state. ${ }^{10}$ Moreover, in the proinflammatory context of collagen-induced arthritis, a mouse model of rheumatoid arthritis, RA has a protective effect against the development of the disease by promoting Foxp $3^{+}$Treg cells, as well as inhibiting the differentiation of autoreactive Th17 cells. ${ }^{32}$ In the EAE model, TGF- $\beta$ protects against disease by inducing Foxp $3^{+}$Treg cells, which migrate into the central nervous system and counterbalance the ratio of effector to Treg cells. ${ }^{33}$ Moreover, this effect is mediated through IL-10. ${ }^{33} \mathrm{We}$ found that while RA induces the expression of TGF- $\beta$ during EAE, the production of IL-10 is decreased (unpublished observations), indicating that RA does not protect against disease by inducing Treg cells. Interestingly, Klemann and colleagues ${ }^{15}$ demonstrated that a RAR $\alpha$ agonist inhibited EAE induced by active immunization. Collectively, these findings suggest that in the context of inflammatory responses, RA can exert immunosuppressive effects on effector T cells. ${ }^{11}$

In this study, we provide further evidence that $\gamma \delta \mathrm{T}$ cells have a significant pathogenic role in EAE, directly or through the activation of Th17 cells. Furthermore, we show that RA can suppress IL-17A and IL-17F production by $\gamma \delta \mathrm{T}$ cells, thereby attenuating their pathogenic activity in vivo in central nervous system autoimmunity. Our results provide new insight into the mechanisms of action of RA and demonstrate that RA selectively inhibits the production of pathogenic cytokines in autoimmune disease. The findings also provide further evidence for the potential of targeting $\gamma \delta \mathrm{T}$ cells in the treatment of autoimmune diseases.

\section{METHODS}

\section{Mice}

C57BL/6 mice (Harlan, Bicester, UK) were bred under specific pathogen free conditions and maintained according to European Union regulations. All experiments were performed under license from the Health Products Regulatory Authority and with approval from the Trinity College Dublin Animal Research Ethics Committee. The mice were co-housed for every EAE experiment.

\section{Stimulation and FACS analysis of peritoneal exudate cells}

Mice were injected intraperitoneally with $250 \mu \mathrm{g}$ of RA or vehicle (dimethyl sulfoxide) in phosphate-buffered saline. After $18 \mathrm{~h}$, the mice were killed and the peritoneal exudate cells collected and cultured for $2 \mathrm{~h}$ with phorbol 12-myristate 13-acetate (Sigma-Aldrich, St Louis, MO, USA, $10 \mathrm{ng} \mathrm{ml}^{-1}$ ), ionomycin (Sigma-Aldrich, $1 \mu \mathrm{g} \mathrm{ml}^{-1}$ ) in the presence of brefeldin A $\left(5 \mu \mathrm{g} \mathrm{ml}^{-1}\right)$. Cytokine production was assessed by intracellular cytokine staining and FACS analysis of the cells.

\section{Induction and assessment of EAE by adoptive transfer}

Donor mice were immunized subcutaneously with $100 \mu \mathrm{g}$ of $\mathrm{MOG}_{35-55}$ peptide (GenScript, Piscataway, NJ, USA) emulsified in complete Freund's adjuvant containing $4 \mathrm{mg} \mathrm{ml}^{-1}$ (0.4 mg per mouse) heat-killed Mycobacterium tuberculosis (Chondrex, Redmond, WA, USA). After 10 days, the mice were killed, their brachial, axillary and inguinal lymph nodes and spleens were collected and a single cell suspension was prepared. The cells were then stimulated for 3 days at a concentration of $10 \times 10^{6}$ cells per $\mathrm{ml}$ with medium, MOG $\left(100 \mu \mathrm{g} \mathrm{ml}^{-1}\right)$ or with MOG, IL-1 $\beta$ (Immunotools, Friesoythe, Germany, $10 \mathrm{ng} \mathrm{ml}^{-1}$ ) and IL-23 (R\&D Systems, $10 \mathrm{ng} \mathrm{ml}^{-1}$ ) and with RA (Enzo, Farmingdale, NY, USA, $10^{-6} \mathrm{M}$ ) or its vehicle (ethanol). In some experiments, $\gamma \delta \mathrm{T}$ cells were purified by magnetic-activated cell sorting (Miltenyi, Bergisch Gladbach, Germany, purity $>90 \%$; Supplementary Figure 1) prior to the culture and either depleted from the culture or added back to the rest of the cells (control). The cells were then stimulated for 3 days with MOG, IL-1 $\beta$ and IL-23. In other experiments, $\gamma \delta \mathrm{T}$ cells were magnetic-activated cell sorting-purified prior to the culture and stimulated separately with IL-1 $\beta$, IL-23 and RA or its vehicle for $6 \mathrm{~h}$. $\gamma \delta$ T cells were washed thoroughly, put back with the rest of the cells and the total cells were then stimulated with MOG, IL-1 $\beta$ and IL-23 for 3 days. Cytokine production was assessed by intracellular cytokine staining and FACS analysis of the cells or by ELISA (R\&D Systems, Minneapolis, MN, USA and BD Biosciences, San Jose, CA, USA) on the supernatants. For transfer to recipient animals, the cells were thoroughly washed and $10-15 \times 10^{6}$ live cells were injected intraperitoneally into co-housed recipient mice. The animals were weighed and monitored for signs of EAE daily. The disease severity was assessed as follows: 0 , no clinical sign; 1 , limp tail; 2 , ataxic gait; 3 , hind limb weakness; 4, hind limb paralysis; 5 , tetraplegia/moribund.

\section{Isolation and FACS analysis of brain cells}

Mice were killed and perfused with phosphate-buffered saline, and their brains were isolated. Brain mononuclear cells were then purified by density gradient centrifugation in Percoll and stimulated for $5 \mathrm{~h}$ with phorbol 12-myristate 13acetate (Sigma-Aldrich, $10 \mathrm{ng} \mathrm{ml}^{-1}$ ), ionomycin (Sigma-Aldrich, $1 \mu \mathrm{g} \mathrm{ml}^{-1}$ ) in the presence of brefeldin $\mathrm{A}\left(5 \mu \mathrm{g} \mathrm{ml}^{-1}\right)$ and then stained for intracellular cytokines and analyzed by FACS.

\section{Purification and culture of $\boldsymbol{\gamma} \boldsymbol{\delta} \mathrm{T}$ cells}

$\gamma \delta \mathrm{T}$ cells were purified from lymph node cells by magnetic-activated cell sorting (purity $>90 \%$; Supplementary Figure 1) and $\mathrm{CD} 27^{+}$and $\mathrm{CD} 27^{-}$or $\mathrm{V} \gamma 1^{+}$and ${\mathrm{V} \gamma 4^{+}}^{+} \delta \mathrm{T}$ cells were sorted by FACS (Dako Moflo, Beckman Coulter, Indianapolis, IN, USA). The cells were stimulated with IL- $1 \beta$ and IL-23 

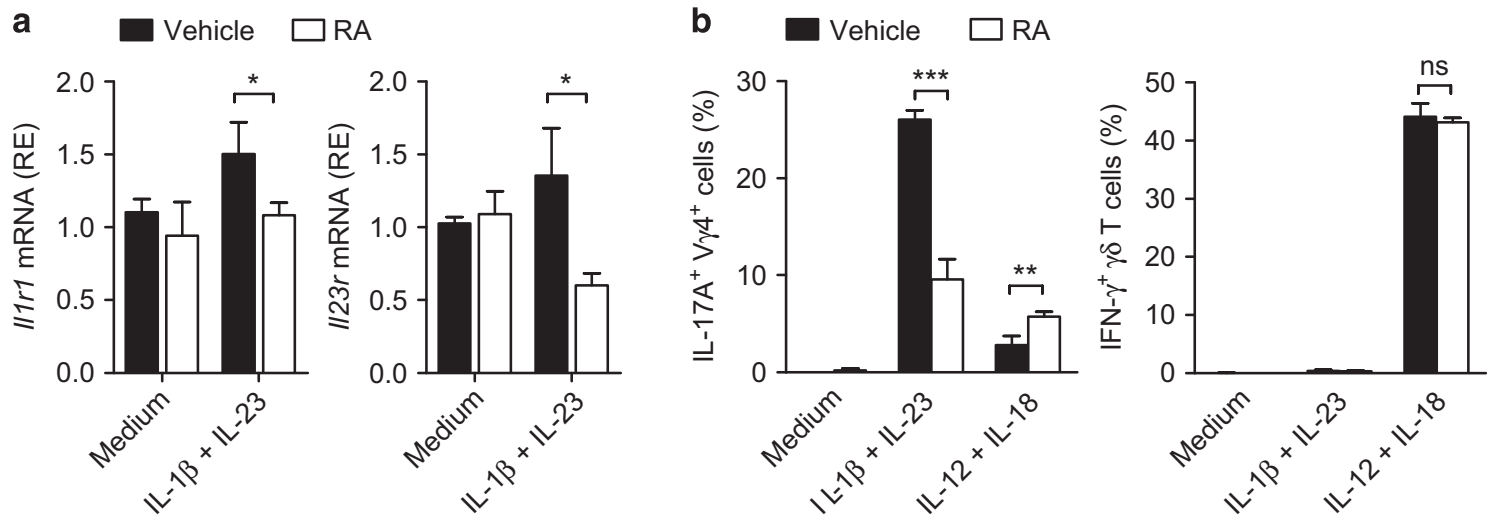

C
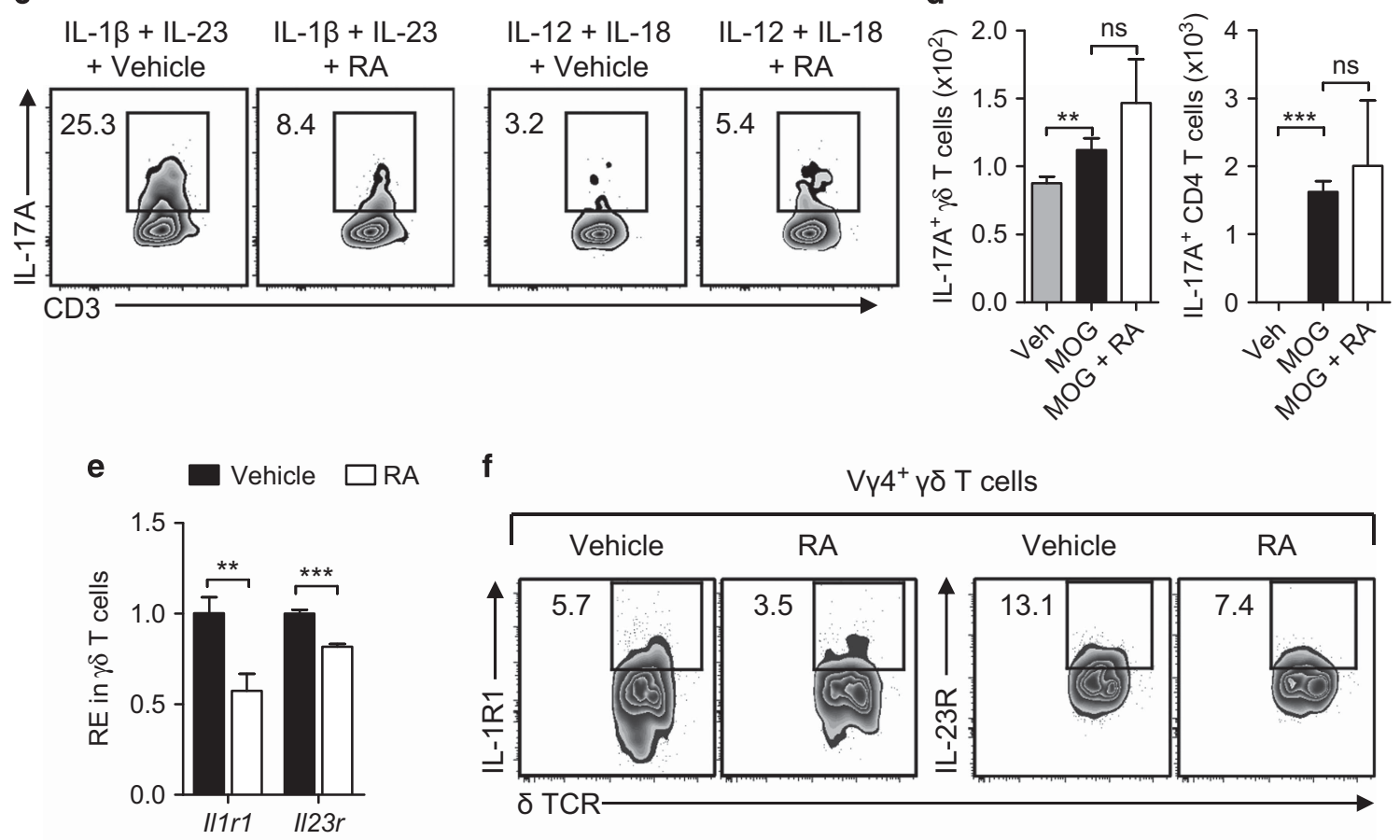

f

$\mathrm{V} Y 4^{+} \mathrm{y} \delta \mathrm{T}$ cells
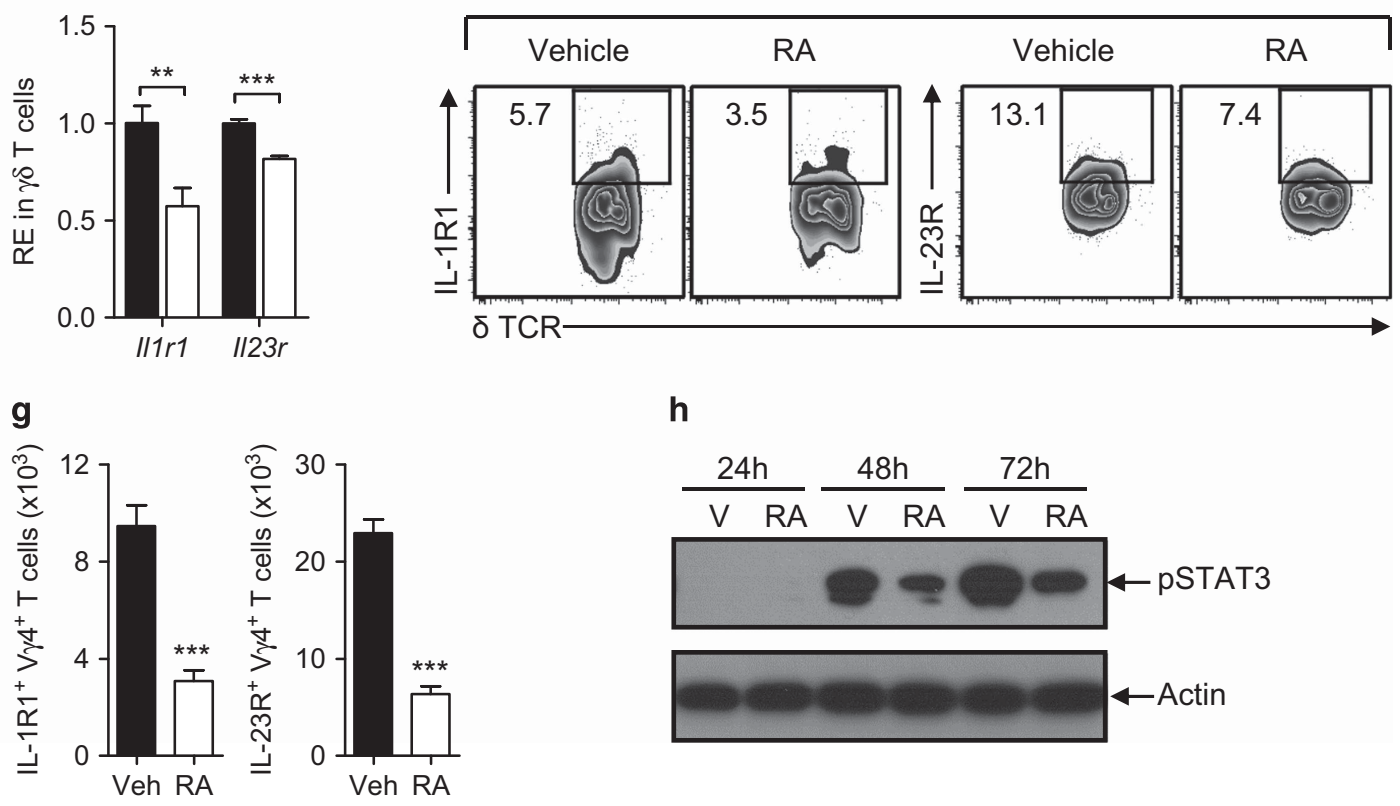

h

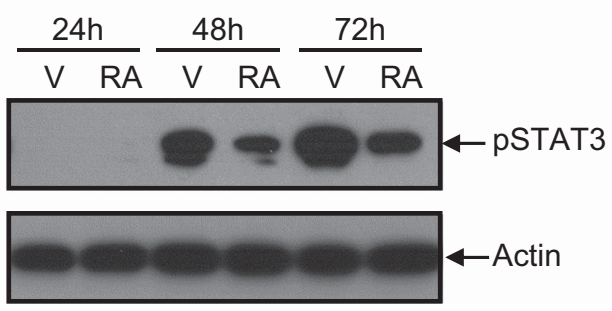

Figure 7 RA impairs the IL-1 $\beta$ and IL-23 pathway in $\gamma \delta$ T cells but does not alter cytokine production induced by IL-12 and IL-18. (a) Relative expression of il 1 r 1 and il23r mRNA measured by RT-PCR in $\gamma \delta \mathrm{T}$ cells purified from naive mice and cultured for $3 \mathrm{~h}$ with IL-1 $\beta+\mathrm{IL}-23$, with or without RA. (b, c) $\gamma \delta$ T cells purified from lymph nodes of naive mice were cultured for $24 \mathrm{~h}$ with IL-1 $\beta+\mathrm{IL}-23$ or IL-12+IL-18, and with or without RA. Mean frequencies (b) and corresponding FACS plots (c) of IL-17A ${ }^{+} \mathrm{V} \gamma 4^{+} \mathrm{CCR}^{+} \gamma \delta \mathrm{T}$ cells and IFN- $\gamma^{+} \gamma \delta \mathrm{T}$ cells in the culture. (d) Cells from MOG-immunized mice were cultured with vehicle, MOG or MOG+RA for $24 \mathrm{~h}$ and absolute numbers of IL-17A+ $\gamma \delta$ T cells and CD4 T cells were determined by FACS. (e-g) Cells from MOG-immunized mice were cultured for 3 days with MOG, IL-1 $\beta$ and IL-23 and either RA or its vehicle. (e) Relative expression of illr1 and il23r mRNA measured by RT-PCR on $\gamma \delta \mathrm{T}$ cells sorted at the end of the 3-day culture. (f, $\mathbf{g})$ Representative FACS plots (f) and mean frequencies (g) of IL-1R 1 and IL-23R expression on $\mathrm{V} \gamma 4^{+}$ T cells after 3 days of culture. (h) Western blots showing the effect of RA on STAT3 phosphorylation (pSTAT3) with actin as a control after 24,48 and $72 \mathrm{~h}$ of culture (V: vehicle). Bars are mean+s.d.; ${ }^{*} P<0.05,{ }^{*} P<0.01$ and ${ }^{* * *} P<0.001$, two-tailed unpaired $t$-test. 
( $\gamma \delta \mathrm{T}$ cells, $\mathrm{V} \gamma 1^{+}$and $\mathrm{V} \gamma 4^{+} \gamma \delta \mathrm{T}$ cells), or with IL-12 and IL-18 ( $\gamma \delta \mathrm{T}$ cells), together with RA $\left(10^{-6} \mathrm{M}\right)$ or its vehicle (ethanol) for $3 \mathrm{~h}$ (RT-PCR), $24 \mathrm{~h}$ (flow cytometry) or $72 \mathrm{~h}$ (ELISA). The concentrations of the cytokines IL-17A, IL-17F and IFN- $\gamma$ in culture supernatants were quantified by ELISA.

\section{Flow cytometry}

Brefeldin A (Sigma-Aldrich, $5 \mu \mathrm{g} \mathrm{ml}^{-1}$ ) was added to the cell cultures for $4 \mathrm{~h}$. Cells were washed before being incubated with a live/dead stain and then surface-stained with antibodies specific for $\mathrm{CD} 3, \mathrm{CD} 4, \mathrm{CD} 8,8 \mathrm{TCR}, \mathrm{V} \gamma 1, \mathrm{~V} \gamma 4$, IL-1R1, IL-23R and CCR6. The cells were washed, fixed and permeabilized using 2\% PFA (Pierce, Walthman, MA, USA) or the Foxp3/Transcription Factor Staining Buffer Set (eBioscience, San Diego, CA, USA), which allow the staining of intranuclear proteins. The cells were stained in $0.5 \%$ saponin (Sigma-Aldrich) or permeabilization buffer (eBioscience) containing antibodies directed against IL-17A, IL-17F, IFN- $\gamma$, GM-CSF, ROR $\gamma$ t, Tbet and Ki67. Cells were analyzed using a flow cytometer LSRFortessa (BD) and the data were analyzed with FloJo software. The FACS profile for the different intracellular and surface proteins analyzed were established by gating on single, then live cells and further on $\mathrm{CD}^{+} \mathrm{TCR}^{+}$for $\gamma \delta \mathrm{T}$ cells; $\mathrm{CD}^{+} \mathrm{TC}^{+} \mathrm{V} 1^{+}$for $\mathrm{V} \gamma 1^{+} \gamma \delta$ $\mathrm{T}$ cells; $\mathrm{CD}^{+}{ }^{+} \mathrm{TCR} \delta^{+} \mathrm{V} \gamma 4^{+}$for $\mathrm{V} \gamma 4^{+} \gamma \delta \mathrm{T}$ cells; $\mathrm{CD}^{+} \mathrm{TCR}^{+} \mathrm{V} \gamma 4^{+} \mathrm{CCR} 6^{+}$for the IL-17A-producing $\mathrm{V} \gamma 4^{+} \gamma \delta \mathrm{T}$ cells; $\mathrm{CD}^{+}{ }^{+} \mathrm{TCR}^{-} \mathrm{CD}^{-}{ }^{-} \mathrm{CD} 4^{+}$for $\mathrm{CD} 4^{+} \mathrm{T}$ cells.

\section{Reverse transcription-PCR}

RNA was extracted from the cells using TRIzol (Invitrogen, Grand Island, NY, USA) and reverse transcribed into cDNA using a High Capacity cDNA Reverse Transcription Kit (Applied Biosystems, Carlsbad, CA, USA). Rara, il17a, ill7f, rorc, illrl and il23r expression were quantified by RT-PCR using commercially available primers and an ABI PRISM7500 Sequence Detection System (Applied Biosystems). The amount of each cytokine was determined by normalization to $18 \mathrm{~S}$ rRNA.

\section{Western blots}

Cells were resuspended in ice-cold lysis buffer $(50 \mathrm{~mm}$ Tris, $150 \mathrm{~mm} \mathrm{NaCl}$, $10 \%$ glycerol, $1 \%$ IGEPAL CA-630, $0.5 \%$ sodium deoxycholate, $0.1 \%$ SDS, $10 \mathrm{~mm} \mathrm{NaF}, 1.5 \mathrm{~mm} \mathrm{Na} \mathrm{NaO}_{4}$ and $1 \mathrm{~mm}$ EDTA), supplemented with SIGMAFAST protease inhibitors (Sigma-Aldrich) and benzonase (Merck Millipore, Billerica, MA, USA, $25 \mathrm{U}$ per cell pellet), and lysed for $30 \mathrm{~min}$ at $4{ }^{\circ} \mathrm{C}$ with rotation. Samples were then centrifuged at $17000 \mathrm{~g}$ for $20 \mathrm{~min}$ at $4^{\circ}$ C. Supernatants were assayed for protein concentration using the Pierce $660 \mathrm{~nm}$ protein assay and diluted to the same protein concentration with lysis buffer. Aliquots corresponding to $10 \mu \mathrm{g}$ of cell protein were diluted with $5 \times$ SDS-PAGE sample buffer, heated to $95^{\circ} \mathrm{C}$ for $10 \mathrm{~min}$ and centrifuged at 12000 $g$ for $5 \mathrm{~min}$ at room temperature. Samples were run on a 10\% SDS-PAGE gel, transferred to polyvinylidene difluoride and analyzed by immunoblot using polyclonal rabbit antibody raised against mouse phospho-STAT3 (Cell Signaling, Danvers, MA, USA), mouse monoclonal antibody raised against beta actin (Abcam, Cambridge, MA, USA), anti-mouse IgG, HRP conjugate (Promega, Fitchburg, WI, USA) and anti-rabbit IgG, HRP conjugate (Dako, Carpinteria, CA, USA).

\section{Statistics}

Statistical analysis was performed using GraphPad Prism 5. Analysis of variance with Bonferroni post-test or Student $t$ test were used to compare statistical differences of means between groups.

\section{CONFLICT OF INTEREST}

The authors declare no conflict of interest.

\section{ACKNOWLEDGEMENTS}

This work was supported by a Science Foundation Ireland Principal investigator grant (\#11/PI/1036) to KHGM and Marie Curie Intra-European Fellowship (\#629498) to MR and KHGM. We thank Barry Moran for assistance with flow cytometry.
1 Sutton CE, Mielke LA, Mills KH. IL-17-producing gammadelta T cells and innate lymphoid cells. Eur J Immunol 2012; 42: 2221-2231.

2 Petermann F, Rothhammer V, Claussen MC, Haas JD, Blanco LR, Heink S et al. gammadelta $T$ cells enhance autoimmunity by restraining regulatory $T$ cell responses via an interleukin-23-dependent mechanism. Immunity 2010; 33: 351-363.

3 Sutton CE, Lalor SJ, Sweeney CM, Brereton CF, Lavelle EC, Mills KH. Interleukin-1 and IL-23 induce innate IL-17 production from gammadelta T cells, amplifying Th17 responses and autoimmunity. Immunity 2009; 31: 331-341.

4 Hirota K, Duarte JH, Veldhoen M, Hornsby E, Li Y, Cua DJ et al. Fate mapping of IL-17producing T cells in inflammatory responses. Nat Immunol 2011; 12: 255-263.

5 Odyniec A, Szczepanik M, Mycko MP, Stasiolek M, Raine CS, Selmaj KW. Gammadelta $\mathrm{T}$ cells enhance the expression of experimental autoimmune encephalomyelitis by promoting antigen presentation and IL-12 production. J Immunol 2004; 173: 682-694.

6 Selmaj K, Brosnan CF, Raine CS. Colocalization of lymphocytes bearing gamma delta T-cell receptor and heat shock protein hsp65+ oligodendrocytes in multiple sclerosis. Proc Natl Acad Sci USA 1991; 88: 6452-6456.

7 Lalor SJ, Dungan LS, Sutton CE, Basdeo SA, Fletcher JM, Mills KH. Caspase-1-processed cytokines IL-1 beta and IL-18 promote IL-17 production by gammadelta and CD4 T cells that mediate autoimmunity. J Immunol 2011; 186: 5738-5748.

8 Wohler JE, Smith SS, Zinn KR, Bullard DC, Barnum SR. Gammadelta T cells in EAE: early trafficking events and cytokine requirements. Eur J Immunol 2009; 39: $1516-1526$.

9 Spahn TW, Issazadah S, Salvin AJ, Weiner HL. Decreased severity of myelin oligodendrocyte glycoprotein peptide 33 - 35-induced experimental autoimmune encephalomyelitis in mice with a disrupted TCR delta chain gene. Eur J Immunol 1999; 29: 4060-4071.

10 Coombes JL, Siddiqui KR, Arancibia-Carcamo CV, Hall J, Sun CM, Belkaid Y et al. A functionally specialized population of mucosal $\mathrm{CD}_{103^{+}} \mathrm{DCs}$ induces Foxp3 ${ }^{+}$ regulatory T cells via a TGF-beta and retinoic acid-dependent mechanism. J Exp Med 2007; 204: 1757-1764.

11 Raverdeau M, Mills KH. Modulation of $\mathrm{T}$ cell and innate immune responses by retinoic Acid. J Immunol 2014; 192: 2953-2958.

12 Mucida D, Park Y, Kim G, Turovskaya O, Scott I, Kronenberg M et al. Reciprocal TH17 and regulatory $T$ cell differentiation mediated by retinoic acid. Science 2007; 317: 256-260.

13 Elias KM, Laurence A, Davidson TS, Stephens G, Kanno Y, Shevach EM et al. Retinoic acid inhibits Th17 polarization and enhances FoxP3 expression through a Stat3/Stat-5 independent signaling pathway. Blood 2008; 111: 1013-1020.

14 Schambach F, Schupp M, Lazar MA, Reiner SL. Activation of retinoic acid receptoralpha favours regulatory $T$ cell induction at the expense of IL-17-secreting $T$ helper cell differentiation. Eur J Immunol 2007; 37: 2396-2399.

15 Klemann C, Raveney BJ, Klemann AK, Ozawa T, von Horsten S, Shudo K et al. Synthetic retinoid AM80 inhibits Th17 cells and ameliorates experimental autoimmune encephalomyelitis. Am J Pathol 2009; 174: 2234-2245.

16 Moline-Velazquez V, Ortega MC, Vila del Sol V, Melero-Jerez C, de Castro F, Clemente D. The synthetic retinoid Am80 delays recovery in a model of multiple sclerosis by modulating myeloid-derived suppressor cell fate and viability. Neurobiol Dis 2014; 67: $149-164$.

17 Zhan XX, Liu Y, Yang JF, Wang GY, Mu L, Zhang TS et al. All-trans-retinoic acid ameliorates experimental allergic encephalomyelitis by affecting dendritic cell and monocyte development. Immunology 2013; 138: 333-345.

18 Mielke LA, Jones SA, Raverdeau M, Higgs R, Stefanska A, Groom JR et al. Retinoic acid expression associates with enhanced IL-22 production by gammadelta T cells and innate lymphoid cells and attenuation of intestinal inflammation. J Exp Med 2013; 210: 1117-1124.

19 Sutton C, Brereton C, Keogh B, Mills KH, Lavelle EC. A crucial role for interleukin (IL)-1 in the induction of IL-17-producing $T$ cells that mediate autoimmune encephalomyelitis. J Exp Med 2006; 203: 1685-1691.

20 Gaffen SL, Jain R, Garg AV, Cua DJ. The IL-23-IL-17 immune axis: from mechanisms to therapeutic testing. Nat Rev Immunol 2014; 14: 585-600.

21 Langrish CL, Chen Y, Blumenschein WM, Mattson J, Basham B, Sedgwick JD et al. IL-23 drives a pathogenic T cell population that induces autoimmune inflammation. J Exp Med 2005; 201: 233-240.

22 Jin W, Dong C. IL-17 cytokines in immunity and inflammation. Emerg Microbes Infect 2013; 2: e60.

23 Komiyama Y, Nakae S, Matsuki T, Nambu A, Ishigame H, Kakuta S et al. IL-17 plays an important role in the development of experimental autoimmune encephalomyelitis. J Immunol 2006; 177: 566-573.

24 Park H, Li Z, Yang XO, Chang SH, Nurieva R, Wang YH et al. A distinct lineage of CD4 T cells regulates tissue inflammation by producing interleukin 17. Nat Immunol 2005; 6: 1133-1141.

25 Roark CL, French JD, Taylor MA, Bendele AM, Born WK, O'Brien RL. Exacerbation of collagen-induced arthritis by oligoclonal, IL-17-producing gamma delta T cells. J Immunol 2007; 179: 5576-5583.

26 Cua DJ, Sherlock J, Chen Y, Murphy CA, Joyce B, Seymour B et al. Interleukin-23 rather than interleukin-12 is the critical cytokine for autoimmune inflammation of the brain. Nature 2003; 421: 744-748.

27 Thakker P, Leach MW, Kuang W, Benoit SE, Leonard JP, Marusic S. IL-23 is critical in the induction but not in the effector phase of experimental autoimmune encephalomyelitis. J Immunol 2007; 178: 2589-2598. 
28 Chen Z, Laurence A, Kanno Y, Pacher-Zavisin M, Zhu BM, Tato C et al. Selective regulatory function of Socs3 in the formation of IL-17-secreting T cells. Proc Natl Acad Sci USA 2006; 103: 8137-8142.

29 Dungan LS, McGuinness NC, Boon L, Lynch MA, Mills KH. Innate IFN-gamma promotes development of experimental autoimmune encephalomyelitis: a role for NK cells and M1 macrophages. Eur J Immunol 2014; 44: 2903-2917.

30 Sun D, Whitaker JN, Huang Z, Liu D, Coleclough C, Wekerle H et al. Myelin antigen-specific $\mathrm{CD}^{+} \mathrm{T}$ cells are encephalitogenic and produce severe disease in C57BL/6 mice. J Immunol 2001; 166: 7579-7587.
31 El-behi M, Rostami A, Ciric B. Current views on the roles of Th1 and Th17 cells in experimental autoimmune encephalomyelitis. J Neuroimmune Pharmacol 2010; 5: 189-197.

32 Kwok SK, Park MK, Cho ML, Oh HJ, Park EM, Lee DG et al. Retinoic acid attenuates rheumatoid inflammation in mice. J Immunol 2012; 189: 1062-1071.

33 Selvaraj RK, Geiger TL. Mitigation of experimental allergic encephalomyelitis by TGFbeta induced $\mathrm{Foxp}^{+}$regulatory $\mathrm{T}$ lymphocytes through the induction of anergy and infectious tolerance. J Immunol 2008; 180: 2830-2838.

The Supplementary Information that accompanies this paper is available on the Immunology and Cell Biology website (http://www.nature.com/icb) 